\title{
Association between Building Characteristics and Indoor Environmental Quality through Post-Occupancy Evaluation
}

\author{
Rafaela Bortolini $^{1}$ (D) and Núria Forcada ${ }^{2, *(D)}$ \\ 1 School of Architecture and Urbanism, Universidade Federal de Pelotas, Benjamin Constant Street, 1359, \\ Pelotas 96010-020, Brazil; rafaela.bortolini@ufpel.edu.br \\ 2 Group of Construction Research and Innovation (GRIC), Department of Project and Construction \\ Engineering (DPCE), Universitat Politècnica de Catalunya (UPC), Colom, 11, Ed. TR5, 08222 Barcelona, Spain \\ * Correspondence: nuria.forcada@upc.edu
}

check for updates

Citation: Bortolini, R.; Forcada, N. Association between Building Characteristics and Indoor Environmental Quality through Post-Occupancy Evaluation. Energies 2021, 14, 1659. https://doi.org/ $10.3390 /$ en14061659

Academic Editor: Vincenzo Costanzo

Received: 23 February 2021

Accepted: 15 March 2021

Published: 17 March 2021

Publisher's Note: MDPI stays neutral with regard to jurisdictional claims in published maps and institutional affiliations.

Copyright: (c) 2021 by the authors. Licensee MDPI, Basel, Switzerland. This article is an open access article distributed under the terms and conditions of the Creative Commons Attribution (CC BY) license (https:// creativecommons.org/licenses/by/ $4.0 /)$.

\begin{abstract}
Post-occupancy evaluations are common tools used to periodically assess Indoor Environmental Quality (IEQ) in tertiary buildings. Although the large amount of data collected from surveys contain valuable information, the influence of building characteristics on IEQ considering the different uses of the rooms and different types of occupants is rarely considered in the evaluation. This study presents an analysis of the association between building characteristics and IEQ in different building rooms (classrooms and offices) and different occupants (students and lecturers) using a post occupancy evaluation survey to 1013 occupants in 26 higher educational buildings in Spain under a Mediterranean climate. This research demonstrated that building characteristics influence IEQ perceptions of the different rooms in tertiary education buildings. The possibility of controlling the lighting, shadows or heating, ventilation air or conditioning (HVAC) systems are the most influential factors when analyzing IEQ. The findings of this research are of interest to facility managers aiming at implementing energy efficiency measures based on user-centric satisfaction or developing maintenance plans focused on IEQ enhancement.
\end{abstract}

Keywords: building characteristics; indoor environmental quality; post occupancy evaluation; occupant's satisfaction

\section{Introduction}

Building performance can be assessed in terms of the indoor air quality, thermal comfort, lighting quality and acoustic quality, generally referred to as Indoor Environmental Quality (IEQ) [1]. Buildings must ensure a safe, healthy, comfortable indoor environment and satisfy the needs and demands of their occupants [1]. Good health and well-being is one of the United Nations' seventeen Sustainable Development Goals (SDGs), which makes an urgent call for all countries to act [2]. The pandemic we are facing this current year is an example of how important a well-designed place is to support the health and comfort of its occupants.

The existing studies have confirmed that subjective post occupancy evaluation (POE) surveys using occupant-centric approaches together with objective building characteristics can help with analyzing IEQ and thus building performance [3].

It is important to monitor occupant satisfaction to provide an opportunity to objectively determine building performance. For instance, the WELL standard recognizes the importance of monitoring occupant comfort and recommends POE surveys once per year [4]. POE surveys provide valuable insights into whether the people who work in the building are satisfied with their indoor environment, which can be useful in determining the degree to which a building successfully promotes and protects its occupants' health and comfort [4].

Previous studies on POE surveys focused on the impact of IEQ on building occupants' satisfaction [5]. These studies revealed that thermal, visual, acoustic and air quality are 
the most common contributing factors to building occupants' satisfaction [6]. However, other factors unrelated to the indoor climate may affect satisfaction in buildings [7]. The building occupants' satisfaction is also affected by control over the indoor environment, layout, size, aesthetics, and type of HVAC, among others [6,7]. IEQ in higher educational buildings can greatly affect the learning process [8-10]. The evidence indicates that their associated facilities have a significant impact on occupants [11].

The effect of IEQ on user satisfaction was investigated in empirical studies, but not how building characteristics (design and facilities) affect IEQ and thus user satisfaction within different rooms.

On the one hand, the IEQ is not homogeneous for the entire building and differences among rooms occur. Spatial mapping allows indoor environmental discomfort to be identified more intuitively by architects, engineers and Facility Manager (FM) professionals, in order to involve them in a joint effort to enhance building performance over time [12].

On the other hand, recent studies have reported that lecturers and students have different occupant satisfaction perceptions in higher educational buildings [13,14].

Therefore, the primary purpose of this paper is to analyze the association between building design factors and IEQ in different building rooms (classrooms and offices) and by different occupants (students and lecturers).

First, a questionnaire survey to evaluate IEQ aspects is depicted (Appendix A). Then, the results of this satisfaction survey, which we administered to 1013 occupants in 26 higher educational buildings, are presented. Finally, the association between IEQ results and the building characteristics is discussed.

The findings of this research are of interest of facility managers aiming at implementing energy efficiency measures based on user-centric satisfaction or developing maintenance plans focused on IEQ enhancement.

\section{Background}

The building parameters that contribute to IEQ, as identified by previous studies, can be divided into three categories: architectural design parameters, such as window-wall ratio (WWR); spatial design parameters, such as layout; and facilities design parameters, such as the type of heating, ventilation air or conditioning (HVAC) system.

Previous studies identified that the façade [7,12] and shadow design [15] can influence an occupant's satisfaction. However, the studies on façade components affecting user satisfaction are limited [16]. Hua et al. [12] found that the satisfaction level with IEQ in workspaces, and especially with visual comfort, was dependent on the solar orientation. The same study revealed that the thermal comfort was low for all orientations in winter and summer, apart from the south-facing limit zone. Kwon et al. [7] stressed that orientation might not be the main cause for user's discomfort but that other factors such as glass components of the building's façade, artificial lighting, and window shade may also have impact on users' visual comfort. Ali et al. [17] revealed that external blinds improve the thermal perception of the occupants due to provide shading from the direct solar radiations and controlling heat gain or loss. Considering thermal and visual satisfaction, Kwon et al. [7] found that window-wall ratio (WWR), which is computed by dividing the glazing areas by the entire exterior wall façade area [7], did not influence thermal comfort satisfaction.

The most commonly used model for evaluating thermal comfort is the heat-balanced predicted mean vote (PMV) model [18]. PMV depends on the indoor air temperature $\left(\mathrm{T}_{\mathrm{a}}\right)$, indoor air velocity $\left(\mathrm{v}_{\mathrm{a}}\right)$, indoor air humidity $\left(\mathrm{HR}_{\mathrm{a}}\right)$, indoor mean radiant temperature $\left(\mathrm{T}_{\mathrm{r}}\right)$, occupant activity level (met) and occupant clothing insulation (Clo). However, for naturally ventilated buildings, thermal comfort was found to differ among building types, outdoor temperatures and climatic regions [19]. Given that behavioral adjustments and psychological adaptations increase occupants' tolerance of wider range of temperatures [20], the adaptive comfort theory considers that the optimal indoor operative temperature relates primarily to the mean outdoor temperature [21]. 
Hua et al. [22] examined the effect of the daylighting design characteristics of an academic building on the indoor visual quality, and on its user satisfaction. This study revealed that occupants in windowed workspaces presented more satisfaction with their visual environment. Moreover, Hua et al. [22] identified a correlation between satisfaction and shade devices. A positive impact was found between horizontal shading and occupant satisfaction regarding various aspects of the visual environment. Higher satisfaction levels were appraised regarding visual comfort of the daylighting by the occupants whose workspaces had exterior horizontal shading [22]. The presence of glare was correlated with dissatisfaction with several characteristics of the visual environment [22].

Some studies revealed a correlation between the spatial layout, the furniture and workplace satisfaction $[23,24]$. The layout is described as the arrangement and limits of a space, while furniture entails the comfort, ergonomics, and functionality of the chairs and workstations [25]. Desk location and office layout were parameters found to influence thermal and visual satisfaction of the users $[7,23]$. Occupants working in perimeter of buildings presented higher levels of satisfaction with their environment than occupants in central workspaces, where no window is available [12]. The amount of space available for each worker was also found to have an influence on occupants' satisfaction in office buildings [6]. Other spatial factors, such as whether individual offices were opened or enclosed, were also found to have impact on satisfaction [26]. For instance, Bourikas et al. [24] found that office occupants were more dissatisfied with the acoustic quality in open-plan and shared office spaces.

Regarding classrooms, Yang et al. [25] revealed that spatial attributes have a higher impact on student perceptions of their learning environments, which includes the layout of the room and the furniture. Seating location was found to have a slightly significant effect on the satisfaction perception of acoustics, furniture and visibility. However, seating location was found not to impact students' perceptions regarding temperature, air quality, artificial lighting, daylight, and room layout [25].

Other studies focused on the association between the type of HVAC system and occupants' satisfaction. Dawe [27] revealed that radiant and all-air buildings do not influence satisfaction with IEQ, but there is a tendency for increased thermal satisfaction in buildings with radiant systems [28]. Brager and Baker [29] analyzed occupant satisfaction in mixed-mode buildings (a combination of natural ventilation from vents or operable windows and mechanical systems) and revealed that the mixed-mode buildings present greater levels of thermal comfort and air quality satisfaction. The possibility of controlling the indoor environment is one important factor influencing satisfaction and perceived comfort [26,30]. This includes control devices such as light switches for personal lighting control, thermostats for temperature control, and types of mechanical ventilation control.

Table 1 summarizes the existing studies analyzing the building and facilities characteristics that are influencing IEQ.

Table 1. Summary of studies on the association between building characteristics and indoor environmental quality (IEQ) through post occupancy evaluations (POEs).

\begin{tabular}{|c|c|c|c|}
\hline Study & Sample & Type & IEQ Influencing Factors \\
\hline Brager and Baker (2009) & 43,220 occupants in 370 buildings & Offices and Academic & Type of heating, ventilation or air conditioning (HVAC) \\
\hline Bluyssen et al. (2011) & 5732 respondents in 59 buildings & Offices & Office layout, personal control \\
\hline Hua et al. (2011) & 75 occupants in 1 building & Academic & Shade control, window-wall ratio (WWR), light control \\
\hline Frontczak et al. (2012) & 397 occupants in 351 buildings & Offices & Room layout \\
\hline Yang et al. (2013) & 627 occupants in 6 classrooms & Academic & Room layout, furniture \\
\hline Hua et al. (2014) & 46 occupants in 1 building & Academic & Orientation, desk location, personal control \\
\hline Nico et al. (2015) & 126 occupants in 2 classrooms & Academic & Temperature control \\
\hline Karmann et al. (2017) & 3892 respondents in 60 buildings & Offices & Type of HVAC \\
\hline Kwon et al. (2019) & 579 occupants in 5 buildings & Offices & Desk location, orientation, and office layout \\
\hline Dawe (2019) & 568 occupants in 8 buildings & Offices & Type of HVAC, personal control \\
\hline Sakellaris et al. (2019) & 7441 occupants in 167 buildings & Offices & Type of control \\
\hline Chen et al. (2020) & 2537 occupants in 6 universities & Academic & Office type, office layout, personal control \\
\hline Bourikas et al. (2021) & 116 occupants in 2 buildings & Offices & Office layout \\
\hline
\end{tabular}




\section{Materials and Methods}

The research approach adopted in this study consisted of the analysis of the results of a POE survey on IEQ aspects. A building's occupants are the best source of information to define comfort requirements [6,31]. POE surveys provide valuable insights into whether people are satisfied with the environmental conditions, and thus measure when a building protects the health and comfort of its occupants. POE surveys can also help to optimize the indoor environment by identifying and evaluating critical aspects of building performance. Based on these evaluations, building design guidance for more objective decisions can be developed [5,32].

A questionnaire survey was developed to evaluate IEQ aspects, including visual, acoustic and thermal $[33,34]$. The questionnaire survey also evaluated the building conservation aspects of the building in total. This questionnaire was administered to the occupants of various university buildings and campuses in Spain. The results of the questionnaire survey were then used to evaluate the correlation between these aspects and the perception of satisfaction in groups of occupants (See Figure 1).

\begin{tabular}{|c|c|}
\hline $\begin{array}{l}\text { 1. Questionnaire survey (IEQ) } \\
\text { Thermal comfort in winter } \\
\text { Thermal comfort in summer } \\
\text { Air quality in winter } \\
\text { Air quality in summer } \\
\text { Lighting quality } \\
\text { Acoustics quality }\end{array}$ & $\begin{array}{l}\text { 2. Building characteristics } \\
\text { Building age } \\
\text { Window-wall ratio (WWR) and } \\
\text { Shade factor } \\
\text { Façade and roof insulation } \\
\text { Occupancy density } \\
\text { Heating and cooling type }\end{array}$ \\
\hline & \\
\hline \multicolumn{2}{|c|}{$\begin{array}{l}\text { 3. Statistical analysis } \\
\text { Goodman and Kruskal's gamma, Spearman correlation and Chi-square } \\
\text { to evaluate the correlation between IEQ and building characteristics. }\end{array}$} \\
\hline
\end{tabular}

Figure 1. Study methodology.

\subsection{Questionnaire Survey}

The questionnaire survey (see Appendix A) included general respondent details, such as gender and age. Respondents were asked to select the building they work or study in and the years they have been working or studying in that building. Participants were asked to include workplace characteristics, including the availability of personal control adjustments such as curtains, operable windows, thermostats and ventilation regulation.

Participants were contacted in October 2017 by email and asked to think of the previous winter and summer to rate their IEQ satisfaction (thermal sensation, air quality, light quality and acoustic quality). The survey used a Likert scale to rate occupants' satisfaction. These aspects were evaluated in relation to academic building zones, including classrooms and offices. Participants were also asked to identify the main causes of dissatisfaction when necessary.

Moreover, respondents were asked to rate their satisfaction in relation to the building's state of preservation. Possible reasons for dissatisfaction with the state of preservation were predefined, and a text entry box was provided to add other reasons. Finally, respondents were asked to rate the level of general satisfaction within the building. An open-ended question was included that allowed respondents to comment on what they personally found relevant. 


\subsection{Statistical Analysis}

Respondents' data and their satisfaction with the IEQ factors were analyzed by room and by type of end user: student and lecturer. The data were analyzed using the Statistical Package for the Social Sciences (SPSS version 17.00).

Both the Goodman and Kruskal's gamma $(\mathrm{G})$ and the Spearman correlation $\left(\mathrm{r}_{\mathrm{s}}\right)$ tests were run to determine the relationship between the respondents' satisfaction and building design characteristics. They analyze the association that exists between two variables measured on an ordinal scale [35]. Goodman and Kruskal's gamma is an association measure between a categorical variable and a continuous one with many tied ranks, such as WWR and shape factor, while Spearman correlation measures the association between a categorical variable, but the continuous ones, such as the construction age, might have lower tied ranks.

Associations below zero mean a negative or inverse relationship while associations above zero means a positive relationship. $\mathrm{G}$ and $\mathrm{r}_{\mathrm{s}}$ range from -1 to $+1 .-1$ and +1 each indicate perfect relationships [35].

For qualitative analysis, the Chi-square $(\chi 2)$ test was used to determine the dependence between type of end user (student/lecturer), rooms (office/classrooms), and occupants' satisfaction with IEQ aspects. The Chi-square test for independence determines the relationship between two categorical variables. This test can be used to compare observed and expected frequencies. The null hypothesis is that the two sets of frequencies (i.e., observed and expected) are the same. An asymptotic significance less than 0.05 between two variables means significant correlation at $95 \%$ confidence interval between them [35].

\section{Results}

\subsection{Buildings' Characteristics}

The occupants' feedback was obtained from a POE survey from 26 higher educational buildings of two university campuses located in Spain. All buildings were in the Mediterranean climate, which is characterized by dry summers and mild, wet winters under the Köppen climate classification [36]. Within this climate, the temperatures range from $4{ }^{\circ} \mathrm{C}$ to $15{ }^{\circ} \mathrm{C}$ in winter, while the average humidity is very constant (between $64 \%$ and $70 \%$ ).

Campus 1 buildings were constructed around the 1990s, have a reinforced concrete structure, flat roofs and masonry facades. Regarding their HVAC systems, some buildings have radiators, while others have air-water systems or splits. Only a few buildings incorporate forced ventilation. Campus 2 is located in a metropolitan area. The construction age ranged from the twentieth century to 2011. In general, none of the buildings incorporated cooling when they were built and multisplits were installed over the years.

The majority of the buildings include single glazed windows, which represent a low level of thermal transmittance $\left(\mathrm{U}\right.$-value $\left.=5.8 \mathrm{~W} / \mathrm{m}^{2} \cdot \mathrm{K}\right)$. The façade and roof insulation have a medium thermal transmittance for most of the sample (see Table 2). Most of the buildings have a high level of shade factor (average of $41 \%$ ). The shade factor is a measure of the percentage of the window area that can be controlled with shading (e.g., solar protection screens). The average of WWR of the sample is $23 \%$. Regarding occupancy density, some buildings have a high occupancy $\left(1.63 \mathrm{~m}^{2} /\right.$ person), while others have a relatively low occupancy density $\left(6.96 \mathrm{~m}^{2} /\right.$ person). Buildings with high occupancy involve classes as the main activity, while buildings with low occupancy mainly comprise lecturers and administrative staff offices. 
Table 2. Buildings' characteristics.

\begin{tabular}{|c|c|c|c|c|c|c|c|c|c|c|c|}
\hline Building & $\begin{array}{l}\text { Area } \\
\left(\mathrm{m}^{2}\right)\end{array}$ & Age & $\begin{array}{l}\text { Façade Insulation } \\
\quad\left(\mathrm{W} / \mathrm{m}^{2} \mathrm{~K}\right)\end{array}$ & $\begin{array}{l}\text { Roof Insulation } \\
\left(\mathrm{W} / \mathrm{m}^{2} \mathrm{~K}\right)\end{array}$ & $\begin{array}{l}\text { Shape } \\
\text { Factor }\end{array}$ & $\begin{array}{c}\text { Shade Factor } \\
(\%)\end{array}$ & $\begin{array}{c}\text { Window Wall } \\
\text { Ratio }\end{array}$ & $\begin{array}{c}\text { Occupancy Density } \\
\left(\mathrm{m}^{2} / \text { person }\right)\end{array}$ & Heating Type & Cooling Type & $\begin{array}{c}\text { Ventilation } \\
\text { System }\end{array}$ \\
\hline A1 & 3967 & 1990 & 0.53 & 0.45 & 0.249 & $15 \%$ & 25 & 1.94 & Radiators & - & natural \\
\hline A2 & 3886 & 1990 & 0.53 & 0.45 & 0.254 & - & 26 & 1.94 & Radiators & - & natural \\
\hline A3 & 3783 & 1991 & 0.53 & 0.45 & 0.156 & $18 \%$ & 23 & 2.76 & Radiators & - & natural \\
\hline A4 & 2674 & 1991 & 0.53 & 0.45 & 0.155 & $0 \%$ & 23 & 1.74 & Radiators & - & natural \\
\hline A5 & 3216 & 1992 & 0.53 & 0.45 & 0.136 & $0 \%$ & 25 & 1.63 & Radiators & - & natural \\
\hline A6 & 3243 & 1992 & 0.53 & 0.45 & 0.159 & $0 \%$ & 23 & 2.01 & Radiators & - & natural \\
\hline B1 & 2478 & 1989 & 0.53 & 0.45 & 0.159 & $34 \%$ & 27 & 4.41 & Radiators & Splits & natural \\
\hline B2 & 1124 & 1990 & 0.53 & & & $0 \%$ & 14 & 5.38 & Radiators & Fan coil + AHU * & mixed \\
\hline B3 & 2262 & 1993 & 0.53 & 0.45 & 0.197 & $15 \%$ & 44 & 4.11 & Fan coil & Fan coil & natural \\
\hline B4 & 5981 & 1994 & 0.53 & 0.45 & & $61 \%$ & 25 & 6.91 & Fan coil & Fan coil & no \\
\hline B6 & 2196 & 1995 & 0.53 & 0.45 & 0.197 & $83 \%$ & 4 & 4.52 & Fan coil & Fan coil & no \\
\hline $\mathrm{C} 1$ & 4334 & 1986 & 0.42 & 0.19 & 0.213 & $74 \%$ & 15 & 4.93 & Radiators & Splits & natural \\
\hline $\mathrm{C} 2$ & 2124 & 1989 & 0.42 & 0.19 & 0.208 & $65 \%$ & 15 & 5.85 & Radiators & Splits & natural \\
\hline $\mathrm{C} 3$ & 4597 & 1993 & 0.73 & 0.41 & 0.149 & $20 \%$ & 17 & 6.12 & Fan coil & Fan coil + AHU & natural \\
\hline $\mathrm{C} 4$ & 4337 & 1995 & 0.73 & 0.41 & & $68 \%$ & 29 & 7.08 & Fan coil & Fan coil + AHU & mixed \\
\hline $\mathrm{C} 6$ & 4072 & 1995 & 0.73 & 0.41 & & $1 \%$ & 21 & 4.14 & Fan coil & Fan coil + AHU & mixed \\
\hline D1 & 4353 & 1986 & 0.42 & 0.19 & 0.2 & $98 \%$ & 27 & 6.05 & Radiators & Splits & natural \\
\hline D2 & 1989 & 1989 & 0.42 & 0.19 & 0.221 & $96 \%$ & 18 & 6.96 & Radiators & Splits & natural \\
\hline D3 & 2529 & 1989 & -0.28 & -0.61 & 0.231 & $45 \%$ & 26 & 4.38 & Radiators & Splits & natural \\
\hline D4 & 2518 & 1990 & 0.72 & 0.39 & 0.197 & $37 \%$ & 28 & 4.37 & Radiators & Splits & natural \\
\hline D5 & 2581 & 1991 & 1.72 & 1.39 & 0.241 & $88 \%$ & 28 & 4.92 & Radiators & Splits & natural \\
\hline D6 & 2678 & 1993 & 0.73 & 0.41 & 0.233 & $89 \%$ & 19 & 4.76 & AHU & $\mathrm{AHU}$ & mixed \\
\hline EPSEB & 13,683 & & 1.78 & 1.2 & 0.28 & - & 37 & 5.35 & Radiant & - & natural \\
\hline ETSAB & 10,301 & & 1.81 & 1.25 & 0.36 & - & 41 & 6.16 & Air-water & - & natural \\
\hline ETSAV & 7767 & 1991 & 1.05 & 0.6 & 0.5 & - & 25 & 6.12 & Radiant & - & natural \\
\hline
\end{tabular}




\subsection{Respondents' Characteristics}

Respondents' data and their satisfaction with the IEQ factors were analyzed by room and by type of occupant: lecturer and student. A total of 1013 satisfaction surveys were completed, which was a large enough sample to achieve normality for statistical analysis.

The lecturers are 48.11 years old on average, ranging between 22 and 66 years oldm while the students are 21 years old on average and between 17 and 46 years old (Table 3). The offices of the regular users vary from individual offices to four occupants per office. They all have natural lighting and ventilation.

Table 3. Sample characteristics.

\begin{tabular}{cccc}
\hline & & Lecturers & Students \\
\hline $\begin{array}{c}\text { Number of } \\
\text { respondents }\end{array}$ & $\mathrm{N}(\%)$ & $298(29.4 \%)$ & $715(70.6 \%)$ \\
\hline Age (years) & Average & 48.11 & 21 \\
& Standard deviation & 9.9 & 3.4 \\
& Minimum & 22 & 17 \\
& Maximum & 69 & 46 \\
\hline
\end{tabular}

\subsection{Descriptive Statistics of the Survey Results}

Table 4 presents the number of answers for each satisfaction level (1-5) for the different indoor environment aspects both in offices and classrooms for the different groups of end users (lecturers and classrooms).

Table 4. Descriptive statistics of the survey results.

\begin{tabular}{ccccccccccccccccc}
\hline \multirow{2}{*}{ Indoor Environment Aspect } & \multicolumn{4}{c}{ Offices (Lecturers) } & \multicolumn{4}{c}{ Classrooms (Lecturers) } & \multicolumn{3}{c}{ Classrooms (Students) } \\
\cline { 2 - 5 } & $\mathbf{1}$ & $\mathbf{2}$ & $\mathbf{3}$ & $\mathbf{4}$ & $\mathbf{5}$ & $\mathbf{1}$ & $\mathbf{2}$ & $\mathbf{3}$ & $\mathbf{4}$ & $\mathbf{5}$ & $\mathbf{1}$ & $\mathbf{2}$ & $\mathbf{3}$ & $\mathbf{4}$ & $\mathbf{5}$ \\
\hline Thermal sensation in winter & 25 & 77 & 58 & 113 & 25 & 17 & 30 & 66 & 63 & 7 & 39 & 74 & 185 & 233 & 74 \\
\hline Thermal sensation in summer & 27 & 70 & 64 & 114 & 20 & 17 & 48 & 68 & 44 & 6 & 50 & 90 & 190 & 215 & 60 \\
\hline Air quality in winter & 18 & 50 & 108 & 105 & 17 & 11 & 27 & 85 & 56 & 4 & 30 & 31 & 213 & 263 & 72 \\
\hline Air quality in summer & 16 & 52 & 99 & 117 & 14 & 11 & 28 & 87 & 43 & 3 & 44 & 55 & 230 & 224 & 62 \\
\hline Lighting quality & 5 & 38 & 71 & 138 & 46 & 3 & 27 & 62 & 85 & 23 & 25 & 62 & 117 & 311 & 188 \\
\hline Acoustic quality & 23 & 65 & 74 & 108 & 28 & 8 & 33 & 74 & 72 & 13 & 32 & 82 & 190 & 277 & 125 \\
\hline
\end{tabular}

\subsection{Association between Building Characteristics and Lighting Quality}

Goodman and Kruskal's gamma was calculated to determine the association between lighting satisfaction and WWR in classrooms and offices. There was a positive correlation between WWR and lighting satisfaction in classrooms, which was statistically significant $(G=0.379, p=0.001<0.05)$. This result indicates that as WWR rises, lighting satisfaction improves. Regarding offices, there was no correlation $(p=0.459>0.05)$.

The same occurred with the analysis between lighting quality and shade factor. In classrooms, there was a negative correlation $(\mathrm{G}=-0.233, p=0.011<0.05)$ which means natural lighting is better without curtains, blinds, etc. and these end users prefer natural rather than artificial lighting in classrooms. In the offices, no correlation was found $(p=0.607>0.05)$, which suggests that artificial lighting is acceptable in these rooms. The main activities of the lecturers and administrative staff in their offices are related to working with computer screens, therefore, the brightness of the computer screen might be a more relevant parameter that influences their lighting satisfaction. 


\subsection{Association between Builidng Characteristics and Thermal Quality in Summer}

Goodman and Kruskal's gamma was run to determine the association between thermal satisfaction in the summer and the windows' thermal insulation in the classrooms and offices. In classrooms, the windows' thermal insulation was found to be correlated with thermal satisfaction $(G=-0.288, p=0.000<0.05)$. In offices there was no correlation $(p=0.260>0.05)$. Therefore, the association between the windows' thermal insulation and thermal satisfaction is not statistically significant in offices. The majority of the classrooms in the sample do not have a cooling system so their thermal comfort in summer depends highly on the thermal loads from the façade insulation. Then, the transmission thermal loads are very important in summer. However, all offices do include cooling systems, which suggests that lecturers do not care about the cost of cooling resulting from the high thermal loads, but about their comfort.

To check the association between the type of cooling (fan coil/fain coil + AHU/splits) and the thermal satisfaction the Chi-square test was used. There is a statistically significant association between the type of cooling and thermal satisfaction in classrooms $(\chi 2=16.456$, $p=0.036<0.05)($ Table 5$)$ but not in offices $(\chi 2=12.806, p=0.119>0.05)$ (Table 6$)$. Most of the offices have cooling systems.

Table 5. Contingence table for thermal satisfaction in summer (classrooms) and type of cooling.

\begin{tabular}{cccccccc}
\hline & \multicolumn{6}{c}{ Thermal Satisfaction in Summer (Classrooms) } \\
\cline { 3 - 8 } & & $\mathbf{1 . 0}$ & $\mathbf{2 . 0}$ & $\mathbf{3 . 0}$ & $\mathbf{4 . 0}$ & $\mathbf{5 . 0}$ & Total \\
\hline \multirow{3}{*}{ Type of cooling } & Air-water & 45 & 82 & 36 & 30 & 6 & 199 \\
& Fan coil & 0 & 5 & 6 & 4 & 0 & 15 \\
& Splits & 4 & 15 & 11 & 12 & 0 & 42 \\
\hline \multirow{2}{*}{ Total } & & 49 & 102 & 53 & 46 & 6 & 256 \\
\hline
\end{tabular}

Table 6. Contingence table for thermal satisfaction in summer (offices) and type of cooling.

\begin{tabular}{cccccccc}
\hline & \multicolumn{6}{c}{ Thermal Satisfaction in Summer (Offices) } \\
\cline { 3 - 8 } & & $\mathbf{1 . 0}$ & $\mathbf{2 . 0}$ & $\mathbf{3 . 0}$ & $\mathbf{4 . 0}$ & $\mathbf{5 . 0}$ & Total \\
\hline \multirow{3}{*}{ Type of cooling } & Air-water & 11 & 21 & 21 & 28 & 4 & 85 \\
& Fan coil & 2 & 12 & 9 & 10 & 0 & 33 \\
& Splits & 3 & 12 & 8 & 30 & 3 & 56 \\
\hline \multirow{2}{*}{ Total } & & 16 & 45 & 38 & 68 & 7 & 174 \\
\hline
\end{tabular}

\subsection{Association between Builidng Characteristics and Thermal Quality in Winter}

The results show that there is no association between windows' thermal insulation and thermal satisfaction in winter-neither in classrooms $(p=0.821>0.05)$ nor in offices $(p=0.789>0.05)$. The heating is well dimensioned so even with the high transmission loads from the façade, the end users only consider if they feel comfortable.

There is no association between the type of heating (fain coil/radiator/AHU)-neither in classrooms $(\chi 2=4.306, p=0.829>0.05)$ (Table 7), nor in offices $\left(\chi^{2}=13.318, p=0.101\right.$ $>0.05$ ) (Table 8). All of them do have heating systems and they are well dimensioned. There is a slight preference for rooms with radiator; in those rooms the thermal satisfaction is higher. The occupants' thermal satisfaction with those buildings heated by Air Handling Units (AHU) is lower than those heated by radiators. The air can cause drafts, air currents, etc. and the control system is more complex although it is more efficient. 
Table 7. Contingence table for thermal satisfaction in winter (classrooms) and type of heating.

\begin{tabular}{cccccccc}
\hline & & \multicolumn{6}{c}{ Thermal Satisfaction in Winter (Classrooms) } \\
\cline { 3 - 8 } & & $\mathbf{1 . 0}$ & $\mathbf{2 . 0}$ & $\mathbf{3 . 0}$ & $\mathbf{4 . 0}$ & $\mathbf{5 . 0}$ & Total \\
\hline \multirow{3}{*}{ Type of heating } & Fan-coil & 12 & 30 & 55 & 72 & 27 & 196 \\
& Radiator & 22 & 67 & 113 & 198 & 65 & 465 \\
& Air-water & 1 & 1 & 3 & 2 & 1 & 8 \\
\hline \multirow{2}{*}{ Total } & & 35 & 98 & 171 & 272 & 93 & 669 \\
\hline
\end{tabular}

Table 8. Contingence table for Thermal satisfaction in winter (offices) and type of heating.

\begin{tabular}{cccccccc}
\hline & & \multicolumn{7}{c}{ Thermal Satisfaction in Winter (Offices) } \\
\cline { 3 - 8 } & & $\mathbf{1 . 0}$ & $\mathbf{2 . 0}$ & $\mathbf{3 . 0}$ & $\mathbf{4 . 0}$ & $\mathbf{5 . 0}$ & Total \\
\hline \multirow{3}{*}{ Type of heating } & Fan-coil & 9 & 22 & 22 & 41 & 4 & 98 \\
& Radiator & 5 & 30 & 8 & 23 & 4 & 70 \\
& Air-water & 1 & 2 & 3 & 5 & 2 & 13 \\
\hline \multirow{2}{*}{ Total } & & 15 & 54 & 33 & 69 & 10 & 181 \\
\hline
\end{tabular}

\subsection{Association between Building Characteristics and Air Quality}

To measure the association between the type of ventilation (natural/mixed/forced) and the satisfaction with the air quality, the Chi-square test was run. The results show that there is a correlation between the type of ventilation in classrooms $(p=0.001)$ but not in offices $(p=0.633)$.

\subsection{Association between Builidng Characteristics and State of Conservaton}

To analyze the correlation between a quantitative variable, the year of construction, and an ordinal variable, satisfaction with the state of conservation, the Spearman correlation test was performed. The results show a slightly positive correlation between the age of the buildings and the level of satisfaction with the state of conservation $\left(\mathrm{r}_{\mathrm{s}}=0.171\right.$, $p=0.00<0.05$ ). The respondents are more satisfied with the state of conservation of newer buildings.

The respondents are also more satisfied in general in newer buildings $\left(\mathrm{r}_{\mathrm{s}}=0.191\right.$, $p=0.000<0.05)$.

\section{Discussion}

IEQ was found to be associated with diverse design parameters. However, differences were found for those rooms occupied by students, such as classes, and those occupied only by lecturers and administrative staff. The specific type of work being undertaken in these spaces and the occupancy density might be the main causes of the different IEQ perceptions.

Lighting quality was found to be associated with the WWR and the shade factor in classrooms but not in offices. All classrooms and offices are windowed but with different WWR and different shade factors. Window shade includes curtains, mobile or fixed blinds, pergolas, and corbels with different materials. Generally, students in classrooms take notes on paper while lecturers work with computers in their offices. The majority of the classes are during the daylight period. When taking notes, the lighting is very important and so is the natural lighting. Although the shade factor of some rooms can be modified (for example, those windows with curtains or mobile blinds), the majority of the shadows in classrooms are fixed (such as fixed blinds, pergolas or corbels) for protecting against radiation and reducing the thermal demand in summer. In offices, the majority of the work is done using computers. In this sense, the natural light might not be so relevant for lighting satisfaction in comparison to the problems derived to the sun reflections on the computer screen. On the other hand, the majority of the shades in offices are mobile 
shades that occupants can adapt to their needs. This is the main reason why the shade factor was not found to be correlated with the lighting satisfaction in offices. Desk location and office layout might also be factors that influence lighting satisfaction [7,23]. Due to the anonymization of the survey results, no data on the desk location of the participants was not requested and no analysis on the office layout and desk location was carried out.

For thermal quality in the summer, differences between classrooms and offices also manifested. These differences are mainly due to the HVAC systems installed in these rooms. The majority of the classrooms $(77.7 \%)$ do not have cooling so the thermal comfort in summer depends highly on the thermal loads from the envelope insulation. The façade insulation is very similar for all rooms but not the types and thermal insulation of the windows. Hereof, although having a higher lighting satisfaction when WWR is high, those rooms without cooling systems should incorporate windows with low thermal transmission glasses or install insulated curtains that can be used when the sunlight directly falls upon the windows; the cost implications are much lower than substituting the glass. The analysis of the different perceptions of lecturers and students in classrooms highlighted that both groups have similar thermal comfort satisfaction for the different types of cooling. The average satisfaction when there is no cooling is 2 for both groups; when fan-coils are installed, students do have a higher thermal comfort (3.5) than lecturers (3) and when splits are installed, there is no difference of thermal perception between the different groups of occupants. Ninety-three per cent of the analyzed offices do have cooling systems whether by fan-coils or by splits.

Surprisingly, no influence was found between the thermal satisfaction in winter in offices and the type of cooling. The results reveal that the occupants are mainly concerned by those noncooled rooms but once they are cooled the type of cooling does not influence thermal comfort. The average outdoor temperatures where the study was carried out were between $4{ }^{\circ} \mathrm{C}$ and $15^{\circ} \mathrm{C}$ in winter, between $10^{\circ} \mathrm{C}$ and $21^{\circ} \mathrm{C}$ in spring and autumn and from $18^{\circ} \mathrm{C}$ to $28^{\circ} \mathrm{C}$ in the summer. These characteristics allow us to conclude that in the winter period heating is required, while for the rest of seasons, control under ventilation can leverage the potential thermal or air quality discomfort.

The envelope characteristics was neither found to be significant for thermal comfort in winter. In fact, when heating is installed, although requiring higher energy consumption due to the low energy performance of the envelope, the end users of tertiary buildings which are not the owners of the company don't care about it.

Regarding air quality satisfaction, no correlation was found in classrooms or in offices-neither in summer nor in winter. All rooms have natural ventilation but not many classrooms do have forced ventilation. In general, summer air quality satisfaction in classrooms were worse rated than in offices. The absence or insufficient use of ventilation systems can provoke high levels of $\mathrm{CO}_{2}$, which might be caused by high occupancy density. Existing regulations make it compulsory for new tertiary buildings to provide forced ventilation [37]. Pawelwargocki et al. [38] confirmed the benefits for health, comfort and productivity of ventilation at a rate greater than the bare minimum required by the current standards and guidelines. However, most of the existing building stock still lacks forced ventilation. Achieving classroom ventilation by manually opening windows is complex because all occupants must agree to open or close windows. Forced ventilation is then a better solution for air renovation in high occupancy rooms. On the other hand, although in the offices there is likewise no forced ventilation, the low occupancy levels allow occupants to open windows for air renovation. Therefore, the results manifest that the type of ventilation system is not associated with the air quality satisfaction but the opportunity to monitor and control the HVAC system. Although not providing the highest comfort, the feeling of controlling the environment provides the occupants higher satisfaction. Furthermore, providing the installation of filters in a forced ventilation system has positive effects on workers' productivity in office buildings since it reduces indoor air pollutants, as shown by [39]. Implementing forced ventilation in existing buildings might not be physically feasible due to the space requirement for ducts and vents. However, allowing control of 
HVAC systems, which is technically feasible, can leverage the potential thermal or air quality discomfort.

When analyzing the satisfaction with the entire building where students or lecturers and administrative staff spend the majority of their time, the construction age of the buildings was found to be significant. Occupants are more satisfied with newer buildings than older ones. Newer buildings were built using the Building Technical Code [37] which involves design parameters related to functionality, safety, accessibility, health and sound insulation. Moreover, new buildings are equipped with modern systems, entrance doors, etc. Differences were also found between students and lecturers and administrative staff regarding the age of the building. In general, lecturers prefer newer buildings than students. This fact might be attributed to "forgiveness factors" [40]. Occupants accept different quality indoor environments depending on their expectations. Lecturers, who have generally been working longer in a building than students, who occupy buildings for less than five years, are more demanding with their workplace because they expect to occupy it for many years, while students know that they will be in the building for a short number of years. Previous studies also found associations between the time spent in a room and the IEQ. Rasheed et al. [41] found that those who spent more time at work were less satisfied with IEQ factors. However, productivity and well-being were found to be affected by the acoustic and air quality.

\section{Conclusions}

This paper presented the results of a satisfaction survey on indoor environment administered to 1013 occupants of 26 academic buildings in the Mediterranean climate. The respondents were asked to rate their satisfaction with thermal comfort, indoor air quality, lighting and acoustics, both in the offices and the classrooms of the building they occupy.

This research demonstrated that building characteristics influence IEQ perceptions of different rooms in tertiary education buildings. The results revealed that:

- $\quad$ Lighting quality is associated with WWR and shade factor in classrooms but not in offices. The different tasks performed in each room might be the cause of this difference, together with the impossibility of controlling shadows in classrooms.

- HVAC is associated with thermal and air quality in summer in classrooms. The high occupancy density and the inexistence of forced ventilation might be the main causes.

- The envelope characteristics are not associated with thermal comfort in winter in offices, suggesting that when heating is installed, although requiring higher energy consumption due to the low energy performance of the envelope, the end users of tertiary buildings don't care about it.

- The age of the building is associated with the global satisfaction of the end users. Occupants are more satisfied with newer buildings mainly because they fulfil stricter regulations in terms of comfort. In general, lecturers prefer newer buildings than students.

The outcomes of this study reinforce the importance of designing adaptable spaces and providing user-centric control of the HVAC and lighting systems. These findings also reveal that in tertiary buildings the implementation of energy efficiency measures must fall on facility managers, who should also provide the occupants with control over their indoor thermal control, operable windows and shades. Providing occupants with control over their lighting elements and indoor environment was shown to improve their satisfaction.

The findings of this study might assist building designers, managers and owners to focus on occupant-centric aspects when designing and managing tertiary education buildings where different type of rooms with different activities coexist. The IEQ of rooms that are permanently occupied need to be carefully analyzed and HVAC, acoustic and lighting systems need to be designed to meet end users' comfort and satisfaction needs.

The number of interviews with students compared to lecturers is the most relevant limitation of this study. However, the results were statistically significant. Future steps will include the analysis of other rooms such as halls, conference rooms or areas for studying. 
Author Contributions: Conceptualization, N.F. and R.B.; methodology, N.F and R.B.; software, R.B.; validation, R.B.; formal analysis, R.B.; investigation, R.B.; resources, N.F.; data curation, N.F.; writing—original draft preparation, N.F.; writing—review and editing, N.F.; visualization, R.B.; supervision, N.F.; project administration, N.F.; funding acquisition, R.B. All authors have read and agreed to the published version of the manuscript.

Funding: This research was funded by the Conselho Nacional de Desenvolvimento Científico e Tecnológico (CNPq), Brazil (grant number 233559/2014-0).

Institutional Review Board Statement: Not applicable.

Informed Consent Statement: Not applicable.

Data Availability Statement: The data presented in this study are available on request from the corresponding author. The data are not publicly available due to confidentiality.

Conflicts of Interest: The authors declare no conflict of interest.

\section{Appendix A}

Section 1. Interviewee details

Sex: Male/Female

Age:

Section 2. Workplace details

Please select the campus you have been working on:

$\square$ Campus Terrassa

Campus Nord

Please select the name of the building you have been working in.

$\square \mathrm{A} 1 / \mathrm{A} 2 / \ldots$

On which floor of the building is your workspace located?

1 st floor/2nd floor...

Please select the room you have been working in:

A101/A102/...

How long have you worked in this building?

$\square$ Less than 1 year

Between 1 and 5 years

Over 5 years

Which of the following do you personally adjust or control in your workspace (tick all the points that apply)?

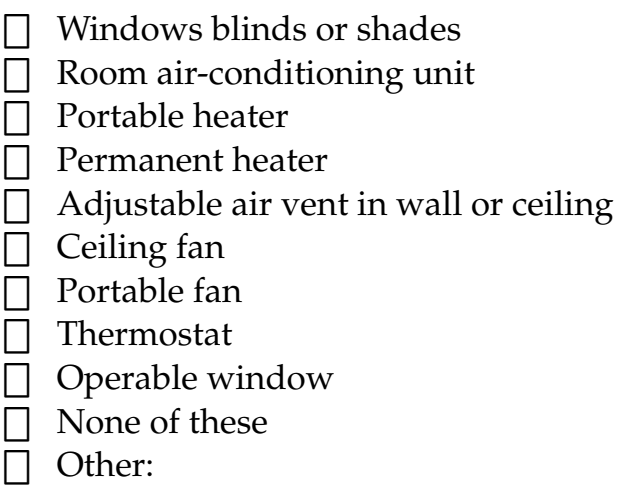

Section 3. Satisfaction with the workplace.

Indicate your degree of satisfaction with the following aspects of your workplace (Very dissatisfied, dissatisfied, neutral, satisfied, very satisfied):

Thermal sensation in summer 
Thermal sensation in wither

Air quality in summer

Air quality in winter

Lighting quality

Acoustic quality

If you are dissatisfied, which of the following contribute to your dissatisfaction:

Thermal quality:

Always too hot

Often too hot

Occasionally too hot

Occasionally too cold

Often too cold

Always too cold

Air quality:

$\square$ The air is stuffy

The air is dry

The air is humid

There are disturbing odours

$\square$ Other:

Lighting quality:

$\square$ Glare of sunlight

Lack of daylight

Dark

Impossibility of controlling lighting

Low level of artificial lighting

High level of artificial lighting

Other:

Acoustic quality

Noise from air conditioning unit

Noise from lights

Noise from exterior machines

People talking loudly in the corridor

Noise from the elevator

No insulation between rooms

Other

Section 4. Satisfaction with other aspects of the building.

How satisfied are you with the state of preservation of the building and its service systems (Very dissatisfied, dissatisfied, neutral, satisfied, very satisfied)?

If you are dissatisfied with the state of preservation of the building, which of the following contribute to your dissatisfaction:

$\square$ Structure vibrating

Façade covering may fall down

Aesthetic problems (wall needs to be painted)

Doors/windows do not work properly

$\square$ Lights burnt out

Elevator not working

Equipment not working (air-conditioner, etc.)

Other:

Indicate your overall satisfaction with the building that you work in (Very dissatisfied, dissatisfied, neutral, satisfied, very satisfied). 


\section{References}

1. Lai, J.H.K.; Man, C.S. Developing a performance evaluation scheme for engineering facilities in commercial buildings: State-ofthe-art review. Int. J. Strat. Prop. Manag. 2017, 21, 41-57. [CrossRef]

2. United Nations. The Sustainable Development Goals Report; United Nations: New York, NY, USA, 2018.

3. Roa, C.D.; Schiavon, S.; Parkinson, T. Targeted occupant surveys: A novel method to effectively relate occupant feedback with environmental conditions. Build. Environ. 2020, 184, 107129. [CrossRef]

4. International Well Building Institute. The WELL Building Standard; International Well Building Institute: New York, NY, USA, 2019.

5. Li, P.; Froese, T.M.; Brager, G. Post-occupancy evaluation: State-of-the-art analysis and state-of-the-practice review. Build. Environ. 2018, 133, 187-202. [CrossRef]

6. Frontczak, M.; Schiavon, S.; Goins, J.; Arens, E.; Zhang, H.; Wargocki, P. Quantitative relationships between occupant satisfaction and satisfaction aspects of indoor environmental quality and building design. Indoor Air 2012, 22, 119-131. [CrossRef]

7. Kwon, M.; Remøy, H.; Bogaard, M. Van Den Influential design factors on occupant satisfaction with indoor environment in workplaces. Build. Environ. 2019, 157, 356-365. [CrossRef]

8. Asif, A.; Zeeshan, M.; Jahanzaib, M. Indoor temperature, relative humidity and $\mathrm{CO}_{2}$ levels assessment in academic buildings with different heating, ventilation and air-conditioning systems. Build. Environ. 2018, 133, 83-90. [CrossRef]

9. Ricciardi, P.; Buratti, C. Environmental quality of university classrooms: Subjective and objective evaluation of the thermal, acoustic, and lighting comfort conditions. Build. Environ. 2018, 127, 23-36. [CrossRef]

10. Bogdanovica, S.; Zemitis, J. The Effect of $\mathrm{CO}_{2}$ Concentration on Children 's Well-Being during the Process of Learning. Energies 2020, 13, 6099. [CrossRef]

11. Abisuga, A.O.; Famakin, I.O.; Oshodi, O.S. Educational building conditions and the health of users. Constr. Econ. Build. 2016, 16, 19-34. [CrossRef]

12. Hua, Y.; Göçer, Ö.; Göçer, K. Spatial mapping of occupant satisfaction and indoor environment quality in a LEED platinum campus building. Build. Environ. 2014, 79, 124-137. [CrossRef]

13. Bortolini, R.; Forcada, N. A probabilistic-based approach to support the comfort performance assessment of existing buildings. J. Clean. Prod. 2019, 237, 117720. [CrossRef]

14. Bortolini, R.; Forcada, N. Regular and temporary occupants' perceptions of satisfaction in tertiary education buildings. Ergonomics 2021, 1-17. [CrossRef]

15. Choi, J.-H.; Loftness, V.; Nou, D.; Tinianov, B.; Yeom, D. Multi-Season Assessment of Occupant Responses to Manual Shading and Dynamic Glass in a Workplace Environment. Energies 2020, 13, 60. [CrossRef]

16. Kwon, M. Impact of design factors on user satisfaction. In Energy-Efficient Office Renovation. Developing Design Principles Based on User-Focused Evaluation; Architecture and the Built Environment, TU Delft: Delft, The Netherlands, 2020; Volume 1, pp. 135-177. ISBN 978-94-6366-240-6.

17. Ali, S.F.; Sharma, L.; Rakshit, D.; Bhattacharjee, B. Influence of Passive Design Parameters on Thermal Comfort of an Office Space in a Building in Delhi. J. Archit. Eng. 2020, 26, 04020017. [CrossRef]

18. Fanger, P.O. Thermal Comfort: Analysis and Applications in Environmental Engineering; Danish Technical Press: Copenhagen, Denmark, 1970.

19. Brager, G.S.; De Dear, R.J. Thermal adaptation in the built environment: A literature review. Energy Build. 1998, 27, 83-96. [CrossRef]

20. Jahan, S.; Hassan, T.; Kumar, M.; Baten, A.; Hossen, S. Status of thermal comfort in naturally ventilated university classrooms of Bangladesh in hot and humid summer season. J. Build. Eng. 2020, 32, 101700. [CrossRef]

21. Yang, D.; Xiong, J.; Liu, W. Adjustments of the adaptive thermal comfort model based on the running mean outdoor temperature for Chinese people: A case study in Changsha China. Build. Environ. 2017, 114, 357-365. [CrossRef]

22. Hua, Y.; Oswald, A.; Yang, X. Effectiveness of daylighting design and occupant visual satisfaction in a LEED Gold laboratory building. Build. Environ. 2011, 46, 54-64. [CrossRef]

23. Bluyssen, P.M.; Aries, M.; van Dommelen, P. Comfort of workers in office buildings: The European HOPE project. Build. Environ. 2011, 46, 280-288. [CrossRef]

24. Bourikas, L.; Gauthier, S.; Khor Song En, N.; Xiong, P. Effect of Thermal, Acoustic and Air Quality Perception Interactions on the Comfort and Satisfaction of People in Office Buildings. Energies 2021, 14, 333. [CrossRef]

25. Yang, Z.; Becerik-Gerber, B.; Mino, L. A study on student perceptions of higher education classrooms: Impact of classroom attributes on student satisfaction and performance. Build. Environ. 2013, 70, 171-188. [CrossRef]

26. Chen, C.F.; Yilmaz, S.; Pisello, A.L.; De Simone, M.; Kim, A.; Hong, T.; Bandurski, K.; Bavaresco, M.V.; Liu, P.L.; Zhu, Y. The impacts of building characteristics, social psychological and cultural factors on indoor environment quality productivity belief. Build. Environ. 2020, 185, 107189. [CrossRef]

27. Dawe, M. Field Evaluation of Occupant Satisfaction and Energy Performance in Eight LEED-Certified Buildings Using Radiant Systems. Master's Thesis, University of California, Berkeley, CA, USA, 2019; 28p.

28. Karmann, C.; Schiavon, S.; Graham, L.T.; Raftery, P.; Bauman, F. Comparing temperature and acoustic satisfaction in 60 radiant and all-air buildings. Build. Environ. 2017, 126, 431-441. [CrossRef]

29. Brager, G.; Baker, L. Occupant satisfaction in mixed-mode buildings. Build. Res. Inf. 2009, 37, 369-380. [CrossRef] 
30. Sakellaris, I.; Saraga, D.; Mandin, C.; de Kluizenaar, Y.; Fossati, S.; Spinazzè, A.; Cattaneo, A.; Szigeti, T.; Mihucz, V.; Fernandes, E.d.O.; et al. Personal control of the indoor environment in offices: Relations with building characteristics, influence on occupant perception and reported symptoms related to the building-the officair project. Appl. Sci. 2019, 9, 3227. [CrossRef]

31. Au-yong, C.P.; Ali, A.S.; Ahmad, F. Improving occupants' satisfaction with effective maintenance management of HVAC system in office buildings. Autom. Constr. 2014, 43, 31-37. [CrossRef]

32. Preiser, W.F. Post-occupancy evaluation: How to make buildings work better. Facilities 1995, 13, 19-28. [CrossRef]

33. Geng, Y.; Ji, W.; Lin, B.; Zhu, Y. The impact of thermal environment on occupant IEQ perception and productivity. Build. Environ. 2017, 121, 158-167. [CrossRef]

34. Rupp, R.F.; Vásquez, N.G.; Lamberts, R. A review of human thermal comfort in the built environment. Energy Build. 2015, 105, 178-205. [CrossRef]

35. Gravetter, F.J.; Wallnau, L.B.; Forzano, L.A.B.; Witnauer, J.E. Statistics for the Behavioral Sciences; Wadsworth Thompson Learning: Belmont, MA, USA, 2020.

36. Beck, H.E.; Zimmermann, N.E.; Mcvicar, T.R.; Vergopolan, N.; Berg, A.; Wood, E.F. Data Descriptor: Present and future Köppen-Geiger climate classification maps at 1-km resolution. Nat. Publ. Gr. 2018,1-12. [CrossRef]

37. Ministerio de Fomento. Código Técnico de la Edificación; Ministerio de Fomento: Madrid, Spain, 2019.

38. Wargocki, P.; Wyon, D.P.; Sundell, J.; Clausen, G.; Fanger, P.O. The Effects of Outdoor Air Supply Rate in an Office on Perceived Air Quality, Sick Building Syndrome. Indoor Air 2000, 10, 222-236. [CrossRef] [PubMed]

39. Becchio, C.; Bottero, M.C.; Corgnati, S.P.; Dell'Anna, F.; Fabi, V.; Lingua, C.; Prendin, L.; Ranieri, M. The effects of indoor and outdoor air pollutants on workers' productivity in office building. E3S Web Conf. 2019, 111. [CrossRef]

40. Leaman, A.; Bordass, B. Are users more tolerant of 'green' buildings? Build. Res. Inf. 2007, 3218. [CrossRef]

41. Rasheed, E.O.; Khoshbakht, M.; Baird, G. Time spent in the office and workers' productivity, comfort and health: A perception study. Build. Environ. 2021, 195, 107747. [CrossRef] 